\title{
Sistem Pendukung Keputusan Penentuan Matakuliah Pilihan Menggunakan Metode TOPSIS (Studi Kasus : Prodi S1 Sistem Informasi FMIPA Universitas Riau)
}

\author{
Sukamto $^{1}$, Aidil Fitriansyah ${ }^{2}$, Rangga Putra Pratama ${ }^{3}$ \\ ${ }^{1,2,3}$ Program Studi Sistem Informasi, FMIPA Universitas Riau \\ Kampus Bina Widya Km. 12,5 Simpang Baru, Pekanbaru, Riau, 28293 \\ e-mail: ${ }^{1}$ sukamto@lecturer.unri.ac.id, ${ }^{2}$ aidil.fitriansyah@lecturer.unri.ac.id, \\ ${ }^{3}$ rangga.putra@gmail.com
}

\begin{abstract}
Abstrak
Matakuliah pilihan juga merupakan matakuliah yang penting, karena pengetahuan dari matakuliah pilihan dapat membantu mahasiswa dalam matakuliah lainnya, skripsi bahkan dalam pekerjaan kedepannya. Maka dari itu, penentuan matakuliah pilihan tidak boleh sembarangan. Tujuan penelitian ini adalah untuk membuat suatu sistem pendukung keputusan berbasis Web untuk membantu mahasiswa Sistem Informasi FMIPA Universitas Riau dalam menentukan matakuliah pilihan yang akan dipilih menggunakan metode Technique for Order Performance of Similarity to Ideal Solution (TOPSIS). TOPSIS mempunyai prinsip bahwa alternatif yang terpilih harus mempunyai jarak terdekat dari solusi ideal positif dan mempunyai jarak terjauh dari solusi ideal negatif. Sistem yang dihasilkan dapat membantu mahasiswa dalam memilih matakuliah pilihan dengan menggunakan kriteria seperti tingkat kesulitan, referensi, lapangan pekerjaan, minat dan bakat. Hasil akhir dari sistem ini adalah lembar hasil perhitungan yang nilai preferensinya telah diurutkan dari yang tertinggi ke terendah. Alternatif dengan nilai tertinggi adalah matakuliah yang direkomendasikan untuk dipilih. Untuk kasus mahasiswa semester IV matakuliah pilihan berdasarkan rangking adalah Data Mining, Perancangan Sumber Daya Perusahaan, dan Pengolahan Citra Digital.
\end{abstract}

Kata kunci: Matakuliah Pilihan, Sistem Pendukung Keputusan, Metode TOPSIS.

\begin{abstract}
Elective courses are as important as other courses, because knowledge from the elective courses can help college students in other courses, minithesis even in the future work. Therefore, determination of elective courses should not be carelessly. The purpose of this research was to make a web-based decision support system to help Riau University Information System's college students in determining the elective courses to be chosen using Technique for Order Performance of Similarity to Ideal Solution (TOPSIS) method. TOPSIS has the principle that the chosen alternative must have the shortest distance from the positive ideal solution and have the farthest distance from the negative ideal solution. The resulting system could help students in choosing elective courses using criteria such as level of difficulty, reference, employment, interests and talents. The final result of this system was a calculation result sheet whose preference values had been sorted from highest to lowest. The alternative with the highest score was the recommended course to choose. For the case of fourth semester students the elective courses based on ranking are Data Mining, Enterprise Resource Design, and Digital Image Processing.
\end{abstract}

Keywords: Decision Support System, Elective Courses, TOPSIS Method. 


\section{Pendahuluan}

Berdasarkan buku pedoman FMIPA Universitas Riau Tahun Akademik 2017/2018, program studi S1 Sistem Informasi memiliki tiga jenis matakuliah, yaitu matakuliah wajib, matakuliah wajib minat, dan matakuliah pilihan. Matakuliah pilihan merupakan matakuliah yang bebas dipilih oleh mahasiswa dengan ketentuan minimal 9 SKS (Satuan Kredit Semester).

Meskipun hanya matakuliah pilihan, penentuan pemilihannya tidak boleh dianggap asal pilih saja. Salah satu masalah yang sering terjadi pada waktu pengisian KRS adalah mahasiswa menentukan matakuliah pilihan yang akan diambil berdasarkan instuisi, pilihan teman, dosen yang baik dalam memberi nilai, atau jadwal yang diinginkan tanpa memperdulikan akibat atau efek yang akan ditimbulkan nantinya.

Adapun tujuan penelitian ini adalah membangun sistem pengambilan keputusan yang dapat menentukan matakuliah pilihan yang akan diambil mahasiswa pada semester tertentu berdasarkan perangkingan matakuliah pilihan (alternatif) yang diurutkan dari nilai preferensi $\left(v_{i}\right)$ yang tertinggi, khususnya di program studi S1 Sistem Informasi Jurusan Ilmu Komputer FMIPA Universitas Riau menggunakan metode TOPSIS.

Pengambilan keputusan adalah proses untuk memilih tindakan diantara beberapa alternatif yang ada, sehingga apa yang menjadi tujuan dapat tercapai [1]. Beberapa penelitian yang membahas tentang metode TOPSIS antara lain, metode TOPSIS untuk menentukan alternatif yang akan dipilih tidak hanya memperhitungkan nilai yang terdekat dengan solusi ideal positif, tetapi juga nilai terjauh dengan solusi ideal negatifnya [2]. Prinsip dalam metode TOPSIS untuk menentukan alternatif yang terpilih harus mempunyai jarak terdekat dari solusi ideal positif dan juga jarak terjauh dari solusi ideal negatif, dengan menggunakan jarak euclidean untuk menentukan kedekatan relatifnya [3]. Metode TOPSIS digunakan untuk perhitungan perangkingan yang memberikan hasil yang sama [4].

Selanjutnya metode TOPSIS banyak digunakan dalam beberapa kasus, antara lain, menentukan penerimaan mahasiswa baru [5], penilaian tingkat kinerja karyawan [6], penerimaan guru kehormatan [7], perangkingan kualitas padi [8], dan rekomendasi evaluasi dosen [9].

Penelitian tentang pemilihan matakuliah pilihan sudah dibahas dengan menggunakan metode AHP yang menyimpulkan bahwa SPK dapat membantu mahasiswa dalam memilih matakuliah pilihan berdasarkan bobot [10].

\section{Metode Penelitian}

\subsection{Pengumpulan Data}

Proses pengumpulan data dilakukan di program studi S1 Sistem Informasi, jurusan Ilmu Komputer FMIPA Universitas Riau, yang meliputi data kurikulum dan data kriteria penilaian.

\subsection{Analisa Sistem}

Metode TOPSIS adalah salah satu metode pengambilan keputusan, yang ide dasarnya adalah alternatif yang dipilih memiliki jarak terdekat dengan solusi ideal dan memiliki jarak terjauh dengan solusi ideal negatif, dengan langkah-langkah sebagai berikut [11]:

a) Membuat matriks keputusan yang ternormalisasi $\left(r=\left[r_{i j}\right]\right)$, dengan

$r_{i j}=\frac{x_{i j}}{\sqrt{\sum_{i=1}^{m} x_{i j}^{a}}}$

dimana $i=1,2, \ldots, n ; r_{i j}$ adalah matriks ternormalisasi, dan $x_{i j}$ adalah matriks keputusan.

b) Menentukan matriks keputusan ternormalisasi terbobot $\left(y=\left[y_{i j}\right]\right)$, dengan

$$
y_{i j}=w_{j}, r_{i j}
$$


dimana $i=1,2, \ldots, n ; j=1,2, \ldots, m ; w_{j}$ adalah bobot kriteria, dan $y_{i j}$ adalah matriks keputusan yang ternormalisasi terbobot.

c) Menentukan matriks solusi ideal positif $\left(A^{+}\right)$dan matriks solusi ideal negatif $\left(A^{-}\right)$, yaitu :

$$
\begin{aligned}
& A^{+}=\left(y_{1^{+}}, y_{2^{+}}, \cdots, y_{j^{+}}\right) \\
& A^{-}=\left(y_{1^{-}}, y_{2^{-}}, \cdots, y_{j^{-}}\right)
\end{aligned}
$$

dengan

$y_{j^{+}}=\left\{\begin{array}{l}\max y_{i j}, \text { jika } j=\text { keuntungan } \\ \min y_{i j}, \text { jika } j=\text { biaya }\end{array}\right\}$
$y_{j^{-}}=\left\{\begin{array}{l}\min y_{i j}, \text { jika } j=\text { keuntungan } \\ \max y_{i j}, \text { jika } j=\text { biaya }\end{array}\right\}$

Jika kriteria bersifat Benefit (makin besar makin baik) maka $y_{j}+=\max y_{i j}$ dan min $y_{i j}$.

Jika kriteria bersifat Cost (makin kecil makin baik) maka $y_{j^{-}}=\min y_{i j}$ dan max $y_{i j}$.

d) Menentukan jarak antara nilai setiap alternatif dengan matriks solusi ideal positif $\left(d_{i}+\right)$ dan matriks solusi ideal negatif $\left(d_{i^{-}}\right)$.

- Jarak solusi ideal positif $\left(d_{i^{+}}\right)$, yaitu :

$$
d_{i+}=\sqrt{\sum_{j=1}^{m}\left(y_{j^{+}}-y_{i j}\right)^{2}}
$$

dimana $i=1,2, \ldots, n ; d_{i}+$ adalah jarak alternatif $A_{i}$ dengan solusi ideal positif, $y_{j}{ }^{+}$adalah solusi ideal positif $[i]$, dan $y_{i j}$ adalah matriks normalisasi terbobot $[i][j]$.

- Jarak solusi ideal positif $\left(d_{i^{-}}\right)$, yaitu :

$$
d_{i^{-}}=\sqrt{\sum_{j=1}^{m}\left(y_{i j}-y_{j^{-}}\right)^{2}}
$$

dimana :

$i=1,2, \ldots, \mathrm{n} ; d_{i}-$ adalah jarak alternatif $A_{i}$ dengan solusi ideal negative, $y_{j^{-}}$adalah solusi ideal negatif $[i]$, dan $y_{i j}$ adalah matriks normalisasi terbobot $[i][j]$

e) Menentukan nilai preferensi $\left(v_{i}\right)$ untuk setiap alternatif :

$$
v_{i}=\frac{d_{i}^{-}}{d_{i}^{-}+d_{i}^{+}}
$$

dimana $v_{i}$ adalah kedekatan tiap alternatif terhadap solusi ideal, $d_{i}^{+}$adalah jarak alternatif $A_{i}$ dengan solusi ideal positif, $d_{i}^{-}$adalah jarak alternatif $A_{i}$ dengan solusi ideal negatif.

Nilai $v_{i}$ yang lebih besar menunjukkan bahwa alternatif $A_{i}$ lebih dipilih.

f) Perangkingan

Alternatif dapat dirangking berdasarkan hasil nilai preferensi $v_{i}$ yang sudah didapat. Alternatif terbaik adalah salah satu yang berjarak terpendek terhadap solusi ideal dan berjarak terjauh dengan solusi ideal negatif.

\subsection{Desain Sistem}

Pembuatan Use Case Diagram dan Class Diagram

\subsection{Implementasi Sistem}

Menggunakan bahasa pemrograman HTML dan PHP, serta MySQL sebagai database. 


\section{Hasil dan Pembahasan}

Penelitian sebelumnya tentang pemilihan matakuliah pilihan sudah dibahas dengan menggunakan metode AHP, sedangkan pada penelitian ini menggunakan metode TOPSIS.

\subsection{Pengumpulan Data}

Hasil pengumpulan data matakuliah pilihan sebagaimana pada Tabel 1.

Tabel 1. Data Matakuliah Pilihan

\begin{tabular}{|l|l|l|c|c|}
\hline No & Kode & Matakuliah & SKS & Semester \\
\hline 1 & MAS2231 & Pengolahan Citra Digital & 3 & 4 \\
\hline 2 & MAS2232 & Perancangan Sumber Daya Perusahaan & 3 & 4 \\
\hline 3 & MAS2233 & Data Mining & $3(2-1)$ & 4 \\
\hline 4 & MAS3131 & Business Intelligence & 3 & 5 \\
\hline 5 & MAS3132 & Sistem Terdistribusi & 3 & 5 \\
\hline 6 & MAS3133 & Sistem Temu Kembali Informasi & 3 & 5 \\
\hline 7 & MAS3134 & Web Lanjut & $3(2-1)$ & 5 \\
\hline 8 & MAS3231 & Analisis Proses Bisnis & 3 & 6 \\
\hline 9 & MAS3232 & Tatakelola dan Audit Sistem Informasi & 3 & 6 \\
\hline 10 & MAS3233 & Pemodelan Data Spasial SPK & $3(2-1)$ & 6 \\
\hline 11 & MAS3234 & Pengindraan Jarak Jauh & 3 & 6 \\
\hline
\end{tabular}

Kriteria matakuliah pilihan dapat dilihat pada Tabel 2, sedangkan bobotnya pada Tabel 3 .

Tabel 2. Kriteria Matakuliah Pilihan

\begin{tabular}{|l|l|c|c|}
\hline Kriteria & Nama Kriteria & Nilai Bobot $\left(\mathrm{w}_{\mathrm{j}}\right)$ & Keterangan \\
\hline C1 & Tingkat Kesulitan & 4 & Cost \\
\hline C2 & Referensi & 3 & Benefit \\
\hline C3 & Lapangan Pekerjaan & 3 & Benefit \\
\hline C4 & Minat & 3 & Benefit \\
\hline C5 & Bakat & 3 & Benefit \\
\hline
\end{tabular}

Tabel 3. Keterangan Nilai Bobot

\begin{tabular}{|c|l|}
\hline Nilai Bobot $\left(\mathrm{w}_{\mathrm{j}}\right)$ & Keterangan \\
\hline 1 & Sangat Rendah \\
\hline 2 & Rendah \\
\hline 3 & Cukup Tinggi \\
\hline 4 & Tinggi \\
\hline 5 & Sangat Tinggi \\
\hline
\end{tabular}

Analisa dibagi menjadi dua kasus, yaitu :

1) Mahasiswa semester IV yang hanya dapat mengambil matakuliah pilihan semester IV, dengan data alternatif sebagaimana pada Tabel 4.

Tabel 4. Penilaian Alternatif Semester IV

\begin{tabular}{|c|c|c|c|c|c|c|}
\hline \multirow{2}{*}{ Alternatif } & \multirow{2}{*}{ Nama Alternatif } & \multicolumn{5}{|c|}{ Kriteria } \\
\hline & & C1 & $\mathrm{C} 2$ & C3 & $\mathrm{C} 4$ & C5 \\
\hline A1 & Pengolahan Citra Digital & 5 & 4 & 4 & 4 & 2 \\
\hline A2 & $\begin{array}{l}\text { Perancangan Sumber Daya } \\
\text { Perusahaan }\end{array}$ & 3 & 3 & 4 & 3 & 3 \\
\hline A3 & Data Mining & 4 & 3 & 4 & 5 & 3 \\
\hline
\end{tabular}

Atau mahasiswa semester $\mathrm{V}$ yang hanya mengambil matakuliah pilihan semester $\mathrm{V}$, dengan data alternatif sebagaimana pada Tabel 5 . 
Tabel 5. Penilaian Alternatif Semester V

\begin{tabular}{|c|l|r|r|r|r|r|}
\hline \multirow{2}{*}{ Alternatif } & \multirow{2}{*}{ Nama Alternatif } & \multicolumn{5}{|c|}{ Kriteria } \\
\cline { 3 - 8 } & & C1 & C2 & C3 & C4 & C5 \\
\hline A1 & Business Intelligence & 5 & 3 & 4 & 3 & 2 \\
\hline A2 & Sistem Terdistribusi & 4 & 3 & 4 & 3 & 4 \\
\hline A3 & Sistem Temu Kembali Informasi & 4 & 3 & 4 & 3 & 4 \\
\hline A4 & Web Lanjut & 5 & 4 & 4 & 4 & 3 \\
\hline
\end{tabular}

2) Mahasiswa semester VI yang dapat mengambil matakuliah pilihan pada semester IV dan VI, dengan data alternatif sebagaimana pada Tabel 6 .

Tabel 6. Penilaian Alternatif Semester VI

\begin{tabular}{|c|l|r|r|r|r|r|}
\hline \multirow{2}{*}{ Alternatif } & \multirow{2}{*}{ Nama Alternatif } & \multicolumn{5}{|c|}{ Kriteria } \\
\cline { 3 - 7 } & & C1 & C2 & C3 & C4 & C5 \\
\hline A1 & Pengolahan Citra Digital & 3 & 4 & 4 & 3 & 4 \\
\hline A2 & Perancangan Sumber Daya Perusahaan & 3 & 2 & 4 & 2 & 3 \\
\hline A3 & Data Mining & 3 & 2 & 3 & 5 & 3 \\
\hline A4 & Analisis Proses Bisnis & 4 & 2 & 3 & 2 & 3 \\
\hline A5 & Tatakelola dan Audit Sistem Informasi & 3 & 4 & 3 & 4 & 4 \\
\hline A6 & Pemodelan Data Spasial SPK & 5 & 2 & 3 & 3 & 3 \\
\hline A7 & Pengindraan Jarak Jauh & 4 & 3 & 3 & 3 & 2 \\
\hline
\end{tabular}

\subsection{Analisa Sistem}

1) Kasus mahasiswa semester IV yang hanya dapat mengambil matakuliah pilihan semester IV Langkah perhitungan metode TOPSIS adalah sebagai berikut :

a) Membuat matriks keputusan yang ternormalisasi $\left(r=\left[r_{i j}\right]\right)$, Dengan menggunakan Tabel 4 dan persamaan (1), diperoleh:

$$
r_{11}=\frac{5}{\sqrt{5^{2}+3^{2}+4^{2}}}=0.70711
$$

Dengan cara yang sama diperoleh $r_{i j}$ sehingga diperoleh matriks keputusan ternomalisasi $r$, yaitu :

$$
r=\left(\begin{array}{lllll}
0.70711 & 0.68599 & 0.57735 & 0.56569 & 0.42640 \\
0.42426 & 0.51450 & 0.57735 & 0.42426 & 0.63960 \\
0.56569 & 0.51450 & 0.57735 & 0.70711 & 0.63960
\end{array}\right)
$$

b) Menentukan matriks keputusan ternormalisasi terbobot $\left(y=\left[y_{i j}\right]\right)$

Dari Tabel 4 diperoleh $W=$ bobot preferensi $(5,4,4,4,2)$, sehingga dengan menggunakan persamaan (2), diperoleh $y_{11}=5 \times 0.70711=3.53555$

Dengan cara yang sama diperoleh $y_{i j}$, sehingga diperoleh matriks keputusan ternomalisasi terbobot $y$, yaitu :

$$
y=\left(\begin{array}{lllll}
3.53553 & 2.74398 & 2.30940 & 2.26274 & 0.85280 \\
1.27279 & 1.54349 & 2.30940 & 1.27279 & 1.91881 \\
2.26274 & 1.54349 & 2.30940 & 3.53553 & 1.91881
\end{array}\right)
$$

c) Menentukan matriks solusi ideal positif $\left(A^{+}\right)$dan matriks solusi ideal negatif $\left(A^{-}\right)$:

- Menentukan matriks solusi ideal positif $\left(A^{+}\right)$

Dengan menggunakan persamaan (5), diperoleh

$y_{1}+=\min (3.53553 ; 1.27279 ; 2.26274)=1.27279$ 


$$
\begin{aligned}
& y_{2}+=\max (2.74398 ; 1.54349 ; 1.54349)=2.74398 \\
& y_{3}+=\max (2.30940 ; 2.30940 ; 2.30940)=2.30940 \\
& y_{4}+=\max (2.26274 ; 1.27279 ; 3.53553)=3.53553 \\
& y_{5}+=\max (0.85280 ; 1.91881 ; 1.91881)=1.91881
\end{aligned}
$$

Sehingga dengan menggunakan persamaan (3)diperoleh:

$A^{+}=(1.27279 ; 2.74398 ; 2.30940 ; 2.26274 ; 1.91881)$.

- Menentukan matriks solusi ideal negatif $\left(\mathrm{A}^{-}\right)$

Dengan menggunakan persamaan (6), diperoleh

$$
\begin{aligned}
& y_{1^{-}}=\max (3.53553 ; 1.27279 ; 2.26274)=3.53553 \\
& y_{2^{-}}=\min (2.74398 ; 1.54349 ; 1.54349)=1.54349 \\
& y_{3^{-}}=\min (2.30940 ; 2.30940 ; 2.30940)=2.30940 \\
& y_{4^{-}}=\min (2.26274 ; 1.27279 ; 1.91881)=1.27279 \\
& y_{5^{-}}=\min (0.85280 ; 1.91881 ; 1.91881)=0.85280
\end{aligned}
$$

Sehingga dengan menggunakan persamaan (4) diperoleh $A^{-}=(3.53553 ; 1.54349 ; 2.30940 ; 1.27279 ; 0.85280)$.

d) Menentukan jarak antara nilai setiap alternatif dengan matriks solusi ideal positif $\left(d_{i}+\right)$ dan matriks solusi ideal negatif $\left(d_{i^{-}}\right)$.

- Jarak solusi ideal positif $\left(d_{i}^{+}\right)$, yaitu :

Dengan menggunakan matriks ternormalisasi terbobot dan persamaan (7), maka :

$$
d_{1^{+}}=\sqrt{\begin{array}{c}
(1.27279-3.53553)^{2}+(2.74398-2.74398)^{2}+(2.30940-2.30940)^{2} \\
+(2.26274-3.53553)^{2}+(1.91881-0.85280)^{2}
\end{array}}=2.80648
$$

Dengan cara yang sama, diperoleh $d_{4^{+}}$, yaitu $d_{2}+=2.56147$ dan $d_{3}+=1.55601$

- Jarak solusi ideal positif $\left(d_{i^{-}}\right)$, yaitu :

Dengan menggunakan matriks ternormalisasi terbobot persamaan (8), maka :

$$
d_{1^{-}}=\sqrt{\begin{array}{c}
(3.53553-3.53553)^{2}+(2.743398-1.54349)^{2}+(2.30940-2.30940)^{2} \\
+(2.26274-1.27279)^{2}+(0.85280-0.85280)^{2}
\end{array}}=
$$

Dengan cara yang sama, diperoleh $d_{i^{-}}$, yaitu $d_{2^{-}}=2.50127$ dan $d_{3^{-}}=2.80648$

e) Menentukan nilai preferensi $\left(v_{i}\right)$ untuk setiap alternatif.

Dengan menggunakan persamaan (9), maka

$$
\begin{aligned}
& v_{1}=\frac{1.55601}{1.55601+2.80648}=0.35667 \\
& v_{2}=\frac{2.50127}{2.50127+2.56147}=0.49405 \\
& v_{3}=\frac{2.80648}{2.80648+1.55601}=0.64332
\end{aligned}
$$


f) Perangkingan

Alternatif dapat dirangking berdasarkan hasil nilai preferensi $v_{i}$ yang sudah didapat. Dari hasil perhitungan di atas, hasil perangkingan dapat dilihat pada Tabel 7.

Tabel 7. Hasil Perangkingan Kasus Semester IV

\begin{tabular}{|c|c|c|c|c|c|c|c|}
\hline \multirow{2}{*}{ Alternatif } & \multicolumn{5}{|c|}{ Kriteria } & \multirow{2}{*}{$\begin{array}{c}\text { Nilai } \\
\text { Preferensi }\end{array}$} & \multirow{2}{*}{ Rangking } \\
\hline & C1 & $\mathrm{C} 2$ & C3 & $\mathrm{C} 4$ & $\mathrm{C} 5$ & & \\
\hline A1 & 5 & 4 & 4 & 4 & 2 & 0.35667 & 3 \\
\hline A2 & 3 & 3 & 4 & 3 & 3 & 0.49405 & 2 \\
\hline A3 & 4 & 3 & 4 & 5 & 3 & 0.64332 & 1 \\
\hline
\end{tabular}

Berdasarkan Tabel 7, $v_{3}$ merupakan nilai preferensi tertinggi yaitu 0.64332. Sehingga diperoleh bahwa alternatif A3 (Data Mining) yang merupakan matakuliah pilihan prioritas yang perlu dipertimbangkan untuk diambil.

2) Mahasiswa semester VI yang dapat mengambil matakuliah pilihan pada semester IV dan VI Langkah perhitungan metode TOPSIS adalah sebagai berikut :

a) Membuat matriks keputusan yang ternormalisasi $\left(r=\left[r_{i j}\right]\right)$, Dengan menggunakan Tabel 6 dan persamaan (1), diperoleh:

$$
r_{11}=\frac{3}{\sqrt{3^{2}+3^{2}+3^{2}+4^{2}+3^{2}+5^{2}+4^{2}}}=0.31108
$$

Dengan cara yang sama diperoleh $r_{i j}$ sehingga diperoleh matriks keputusan ternomalisasi $r$, yaitu :

$$
r=\left(\begin{array}{lllll}
0.31108 & 0.52981 & 0.45584 & 0.34412 & 0.47140 \\
0.31108 & 0.26490 & 0.45584 & 0.22941 & 0.35355 \\
0.31108 & 0.26490 & 0.34188 & 0.57353 & 0.35355 \\
0.41478 & 0.26490 & 0.34188 & 0.22941 & 0.35355 \\
0.31108 & 0.52981 & 0.34188 & 0.45883 & 0.47140 \\
0.51847 & 0.26490 & 0.34188 & 0.34412 & 0.35355 \\
0.41478 & 0.39736 & 0.34188 & 0.34412 & 0.23570
\end{array}\right)
$$

b) Menentukan matriks keputusan ternormalisasi terbobot $\left(y=\left[y_{i j}\right]\right)$

Dari Tabel 5 diperoleh $W=$ bobot preferensi $(3,4,4,3,4)$, sehingga dengan menggunakan persamaan (2), diperoleh $y_{11}=3 \times 0.31108=0.93324$

Dengan cara yang sama diperoleh $y_{i j}$, sehingga diperoleh matriks keputusan ternomalisasi terbobot $y$, yaitu :

$$
y=\left(\begin{array}{lllll}
0.93326 & 2.11925 & 1.82337 & 1.03237 & 1.88562 \\
0.93326 & 0.52981 & 1.82337 & 0.45883 & 1.06066 \\
0.93326 & 0.52981 & 1.02565 & 2.86770 & 1.06066 \\
1.65912 & 0.52981 & 1.02565 & 0.45883 & 1.06066 \\
0.93326 & 2.11925 & 1.02565 & 1.83533 & 1.88562 \\
2.59238 & 0.52981 & 1.02565 & 1.03237 & 1.06066 \\
1.65912 & 1.19208 & 1.02565 & 1.03237 & 0.47140
\end{array}\right)
$$

c) Menentukan matriks solusi ideal positif $\left(A^{+}\right)$dan matriks solusi ideal negatif $\left(A^{-}\right)$:

- Menentukan matriks solusi ideal positif $\left(A^{+}\right)$

Dengan menggunakan persamaan (5), diperoleh

$y_{1}+=\min (0.93326 ; 0.93326 ; 0.93326 ; 1.65912 ; 0.93326 ; 2.59238 ; 1.65912)=0.93326$

$y_{2}+=\max (2.11925 ; 0.52981 ; 0.52981 ; 0.52981 ; 2.11925 ; 0.52981 ; 1.19208)=2.11925$ 
$y_{3}+=\max (1.82337 ; 1.82337 ; 1.02565 ; 1.02565 ; 1.02565 ; 1.02565 ; 1.02565)=1.82337$

$y_{4}+=\max (1.03237 ; 0.45883 ; 2.86770 ; 0.45883 ; 1.83533 ; 1.03237 ; 1.03237)=2.86770$

$y_{5}+=\max (1.88562 ; 1.06066 ; 1.06066 ; 1.06066 ; 1.88562 ; 1.06066 ; 0.47140)=1.88562$

Sehingga dengan menggunakan persamaan (3)diperoleh:

$A^{+}=(0.93326,2.11925,1.82337,2.86770,1.88562)$.

- Menentukan matriks solusi ideal negatif $\left(\mathrm{A}^{\top}\right)$

Dengan menggunakan persamaan (6), diperoleh

$y_{1^{-}}=\max (0.93326 ; 0.93326 ; 0.93326 ; 1.65912 ; 0.93326 ; 2.59238 ; 1.65912)=2.59238$

$y_{2^{-}}=\min (2.11925 ; 0.52981 ; 0.52981 ; 0.52981 ; 2.11925 ; 0.52981 ; 1.19208)=0.52981$

$y_{3^{-}}=\min (1.82337 ; 1.82337 ; 1.02565 ; 1.02565 ; 1.02565 ; 1.02565 ; 1.02565)=1.02565$

$y_{4^{-}}=\min (1.03237 ; 0.45883 ; 2.86770 ; 0.45883 ; 1.83533 ; 1.03237 ; 1.03237)=0.45883$

$y_{5^{-}}=\min (1.88562 ; 1.06066 ; 1.06066 ; 1.06066 ; 1.88562 ; 1.06066 ; 0.47140)=0.47140$

Sehingga dengan menggunakan persamaan (4) diperoleh

$A^{-}=(2.59238 ; 0.52981 ; 1.02565 ; 0.45883 ; 0.47140)$.

d) Menentukan jarak antara nilai setiap alternatif dengan matriks solusi ideal positif $\left(d_{i^{+}}\right)$dan matriks solusi ideal negatif $\left(d_{i^{-}}\right)$.

- Jarak solusi ideal positif $\left(d_{i}+\right)$, yaitu :

Dengan menggunakan matriks ternormalisasi terbobot dan persamaan (7), maka :

$$
d_{1^{+}}=\sqrt{\begin{array}{c}
(0.93326-0.93326)^{2}+(2.11925-2.11925)^{2}+(1.82337-1.82337)^{2} \\
+(2.86770-1.03237)^{2}+(1.88562-1.88562)^{2}
\end{array}}=
$$

1.83533

Dengan cara yang sama, diperoleh $d_{i^{+}}$, yaitu $d_{2}+=3.00158, d_{3}+=1.96042, d_{4}+=$ $3.18947, d_{5}+=1.30467, d_{6}+=3.15663$, dan $d_{7}+=2.71870$

- Jarak solusi ideal positif $\left(d_{i^{-}}\right)$, yaitu :

Dengan menggunakan matriks ternormalisasi terbobot persamaan (8), maka :

$$
d_{1^{-}}=\sqrt{\begin{array}{c}
(0.93326-2.59238)^{2}+(2.11925-0.52981)^{2}+(1.82337-1.02565)^{2} \\
+(1.03237-0.45883)^{2}+(1.88562-0.47140)^{2}
\end{array}}=
$$

2.87129

Dengan cara yang sama, diperoleh $d_{i^{-}}$, yaitu $d_{2^{-}}=1.93294, d_{3^{-}}=2.98371, d_{4^{-}}=1.10372$, $d_{5^{-}}=3.02882, d_{6^{-}}=0.82230$, dan $d_{7^{-}}=1.28004$

e) Menentukan nilai preferensi $\left(v_{i}\right)$ untuk setiap alternatif.

Dengan menggunakan persamaan (9), maka

$$
v_{1}=\frac{2.87129}{2.87129+1.83533}=0.61005
$$

Dengan cara yang sama, diperoleh $v_{i}$, yaitu $v_{2}=0.39172, v_{3}=0.60349, v_{4}=0.25708, v_{5}=$ $0.69893, v_{6}=0.20666$, dan $v_{7}=0.32011$ 
f) Perangkingan

Alternatif dapat dirangking berdasarkan hasil nilai preferensi $v_{i}$ yang sudah didapat. Dari hasil perhitungan di atas, hasil perangkingan dapat dilihat pada Tabel 8.

Tabel 8. Hasil Perangkingan Kasus Semester VI

\begin{tabular}{|c|c|c|c|c|c|c|c|}
\hline \multirow{2}{*}{ Alternatif } & \multicolumn{5}{|c|}{ Kriteria } & \multirow{2}{*}{$\begin{array}{l}\text { Nilai } \\
\text { Preferensi }\end{array}$} & \multirow[t]{2}{*}{ Rangking } \\
\hline & $\mathrm{C} 1$ & $\mathrm{C} 2$ & $\mathrm{C} 3$ & $\mathrm{C} 4$ & $\mathrm{C} 5$ & & \\
\hline A1 & 3 & 4 & 4 & 3 & 4 & 0.61005 & 2 \\
\hline A2 & 3 & 2 & 4 & 2 & 3 & 039172 & 4 \\
\hline A3 & 3 & 2 & 3 & 5 & 3 & 0.60349 & 3 \\
\hline A4 & 4 & 2 & 3 & 2 & 3 & 0.25708 & 7 \\
\hline A5 & 3 & 4 & 3 & 4 & 4 & 0.69893 & 1 \\
\hline A6 & 5 & 2 & 3 & 3 & 3 & 0.30666 & 6 \\
\hline A7 & 4 & 3 & 3 & 3 & 2 & 0.32011 & 5 \\
\hline
\end{tabular}

Berdasarkan Tabel $8, v_{5}$ merupakan nilai preferensi tertinggi yaitu 0.69893. Sehingga diperoleh bahwa alternatif A5 (Tatakelola dan Audit Sistem Informasi) yang merupakan matakuliah pilihan prioritas yang perlu dipertimbangkan untuk diambil.

\subsection{Desain Sistem}

a) Use case diagram: dapat dilihat pada Gambar 1.

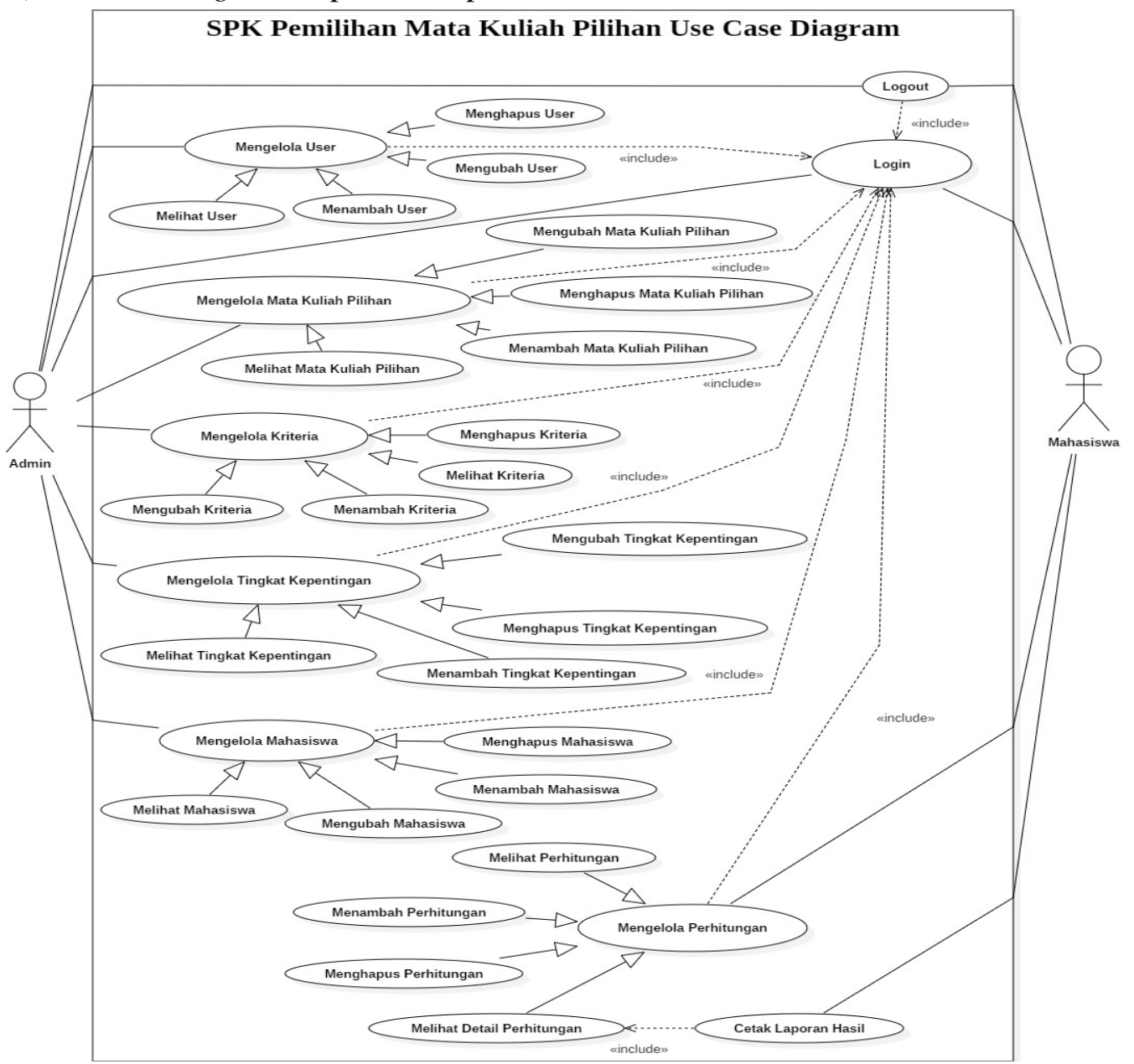

Gambar 1. Use Case Diagram 
b) Class Diagram: dapat dilihat pada Gambar 2.

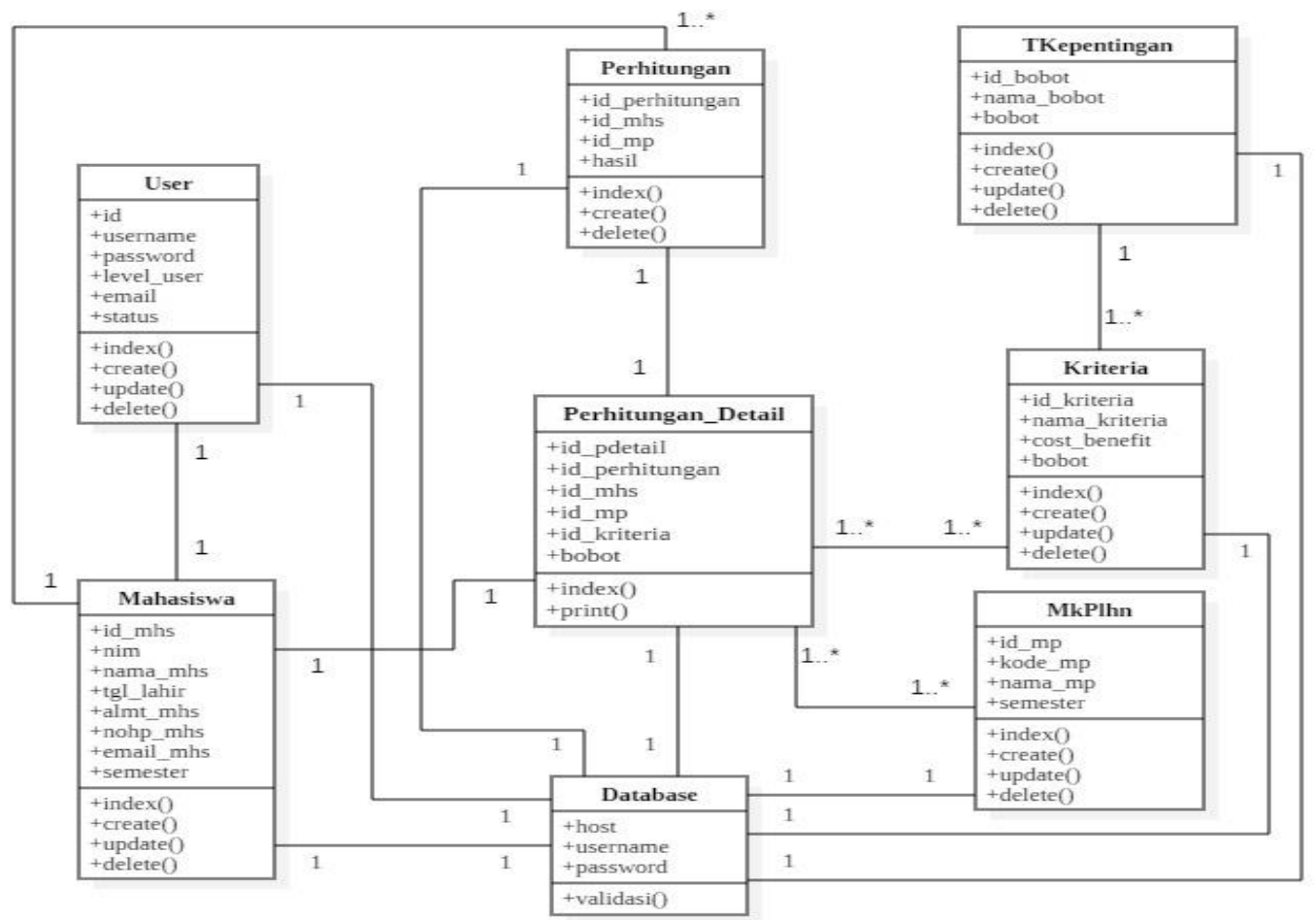

Gambar 2. Class Diagram

\subsection{Implementasi Sistem}

Dalam sistem ini, pengguna dibagi menjadi dua, yaitu :

a) Admin, yang mempunyai hak akses meliputi mengelola data mahasiswa, data matakuliah pilihan, data kriteria, dan data bobot.

b) Mahasiswa (user), yang mempunyai hak akses mengelola data perhitungan.

Adapun hasil implementasi adalah sebagai berikut:

a) Tampilan Halaman Login: digunakan untuk mengatur hak akses pengguna sistem (admin atau user), dimana admin atau user harus menginputkan username dan password untuk bisa masuk ke sistem. Lihat pada Gambar 3.

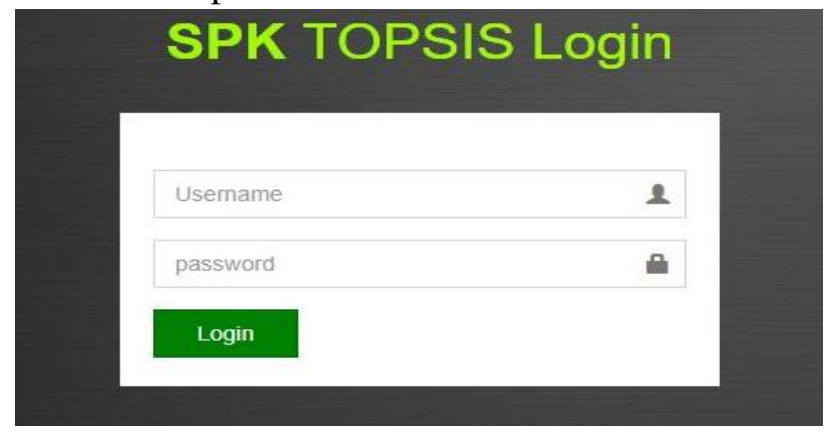

Gambar 3. Halaman Login 
b) Tampilan Halaman Utama: jika login yang dilakukan oleh admin benar, maka akan tampil halaman utama untuk admin. Lihat Gambar 4. Sedangkan untuk user akan langsung ke tampilan perhitungan (Gambar 10).

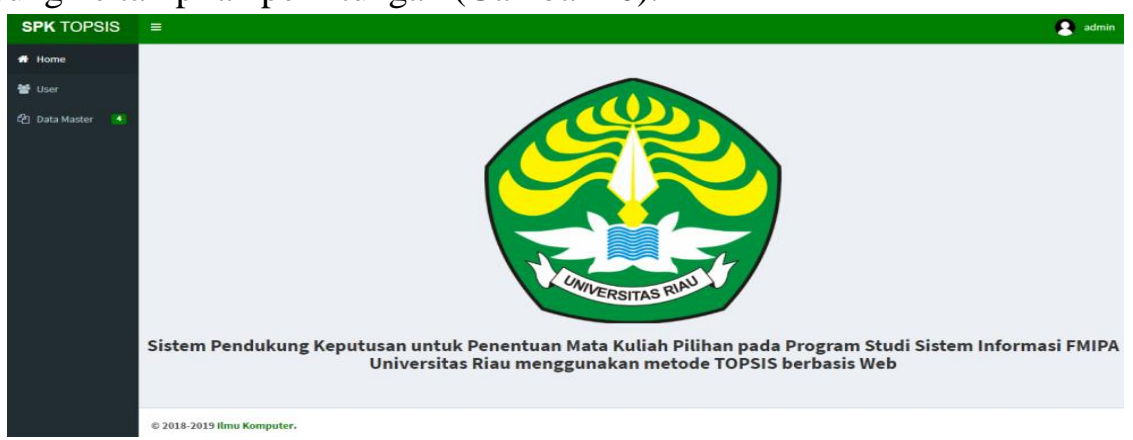

Gambar 4. Halaman Utama Admin

Pada Menu Data Master terdapat submenu Matakuliah Pilihan, Mahasiswa, Kriteria, dan Bobot.

c) Tampilan Halaman Mengelola user, dimana admin dapat mengelola data user, seperti menambah, mengubah, menghapus, serta mencari, yang meliputi Username, E-mail, Level, dan Status. Lihat pada Gambar 5.

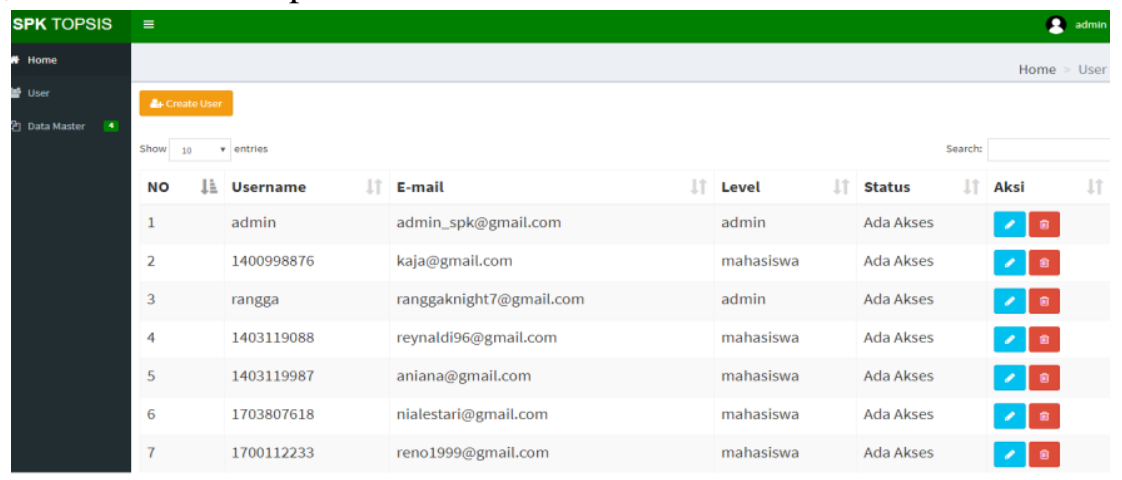

Gambar 5. Halaman Mengelola User

d) Tampilan Halaman Mengelola Matakuliah Pilihan, dimana admin dapat mengelola data matakuliah pilihan yang ada, seperti menambah, mengubah, menghapus, serta mencari, yang meliputi Kode Matakuliah, Nama Matakuliah, dan Semester. Lihat pada Gambar 6.

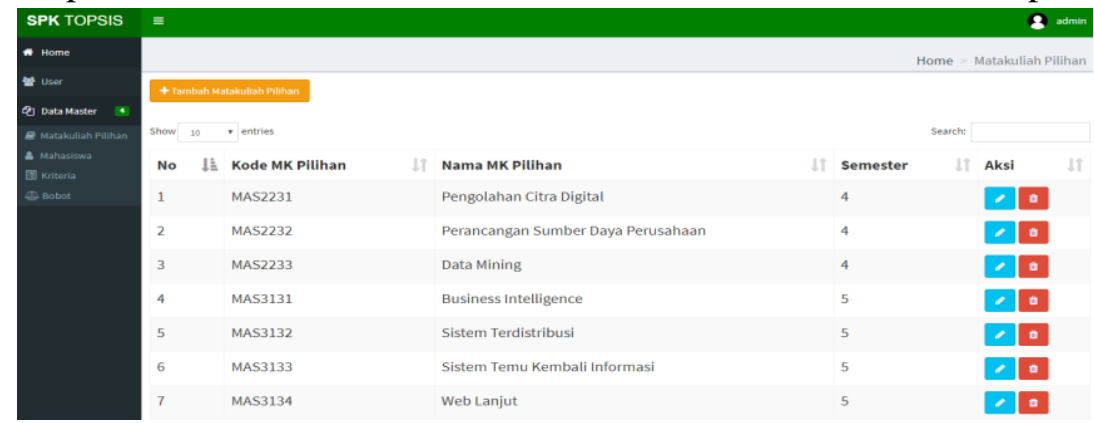

Gambar 6. Halaman Mengelola Matakuliah Pilihan 
e) Tampilan Halaman Mengelola mahasiswa, dimana admin dapat mengelola data Mahasiswa, seperti menambah, mengubah, menghapus, serta mencari, yang NIM, Nama Mahasiswa, Tanggal Lahir, Alamat, No. HP, E-mail, Semester. Lihat pada Gambar 7.

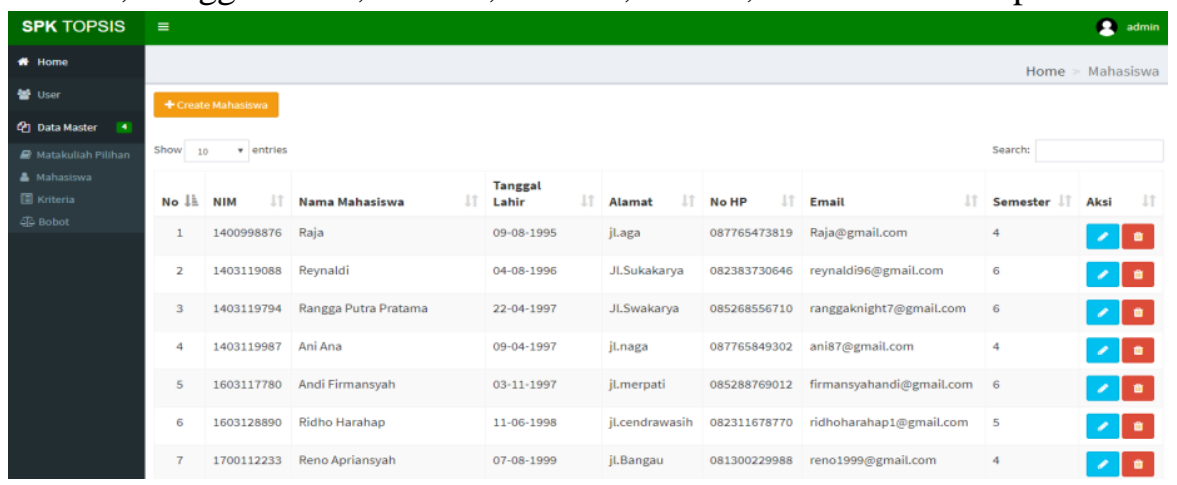

Gambar 7. Halaman Mengelola Mahasiswa

f) Tampilan Halaman Mengelola Kriteria, dimana admin dapat mengelola data kriteria, seperti menambah, mengubah, menghapus, serta mencari, yang meliputi Nama Kriteria, Cost/Benefit, dan Bobot. Lihat pada Gambar 8.

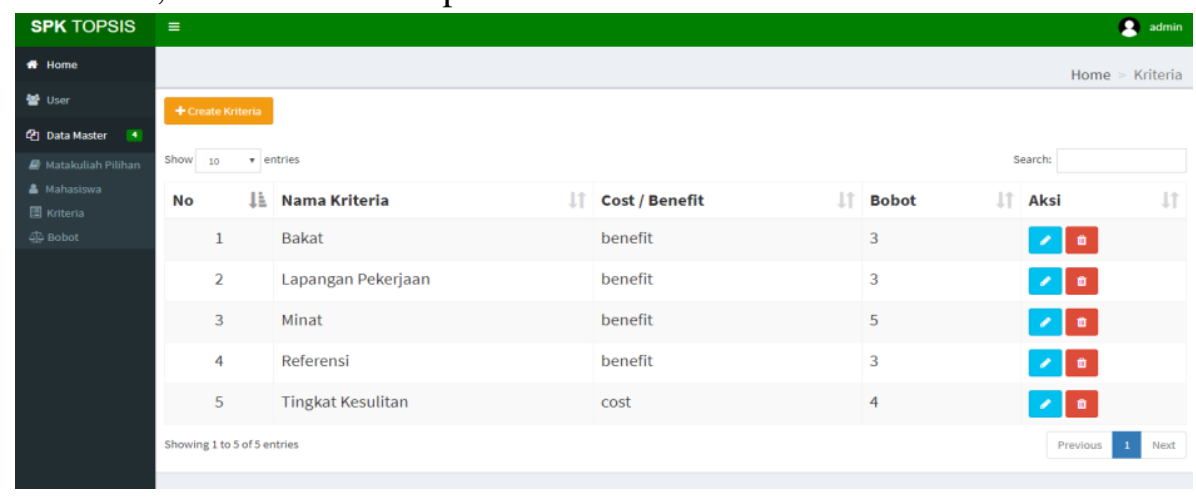

Gambar 8. Halaman Mengelola Kriteria

g) Tampilan Halaman Mengelola Bobot, dimana admin dapat mengelola data bobot, seperti menambah, mengubah, menghapus, serta mencari, yang meliputi Nama Bobot dan Bobot. Lihat pada Gambar 9.

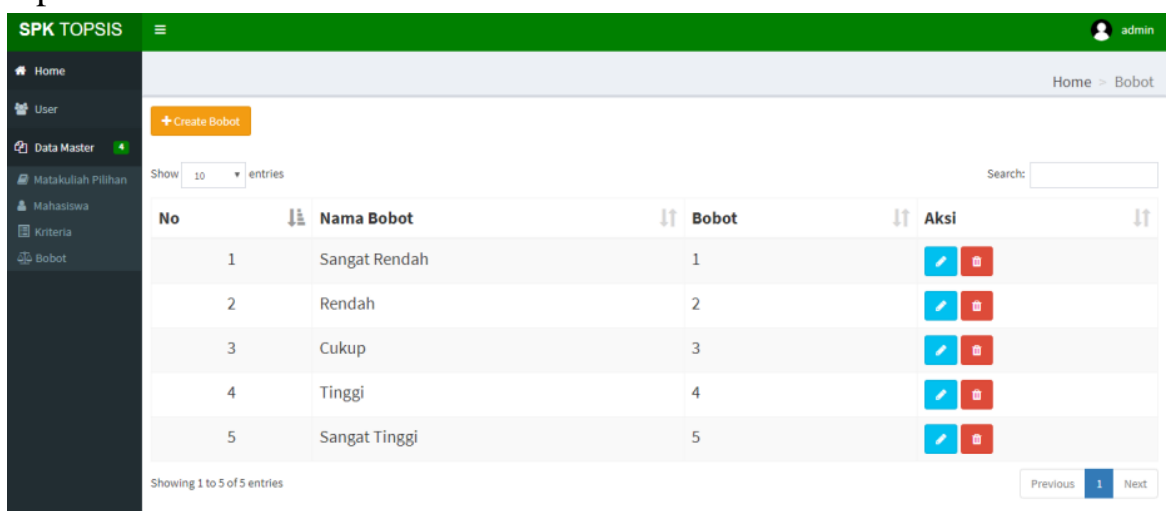

Gambar 9. Halaman Mengelola Bobot 
h) Tampilan Halaman Mengelola Perhitungan, yang bisa diakses oleh user (mahasiswa), dimana pada halaman ini mahasiswa dapat menambah ataupun menghapus data perhitungan. Lihat pada Gambar 10.

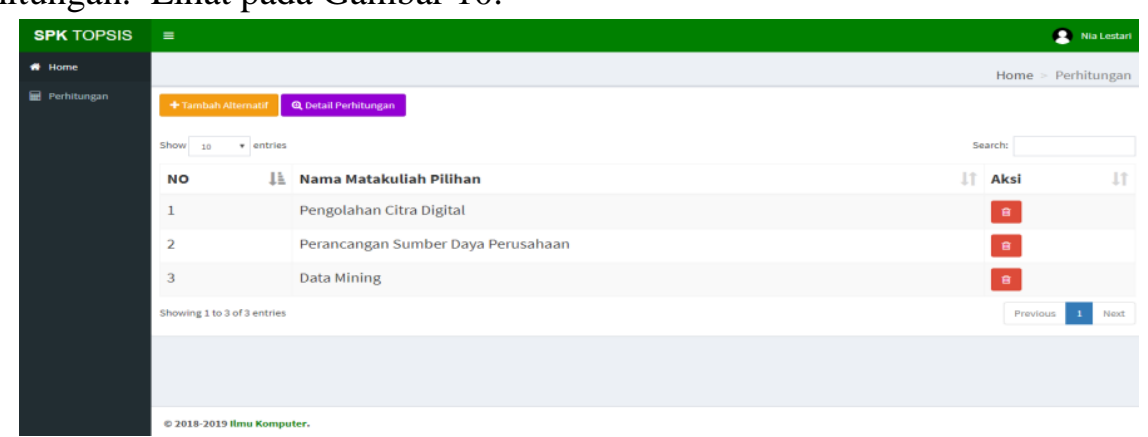

Gambar 10. Halaman Mengelola Perhitungan

i) Tampilan Halaman Tambah Perhitungan, tergantung semester mahasiswa (IV, V, VI), jika mahasiswa semester IV, maka matakuliah pilihan yang ditampilkan adalah matakuliah pilihan semester IV. Lihat pada Gambar 11.

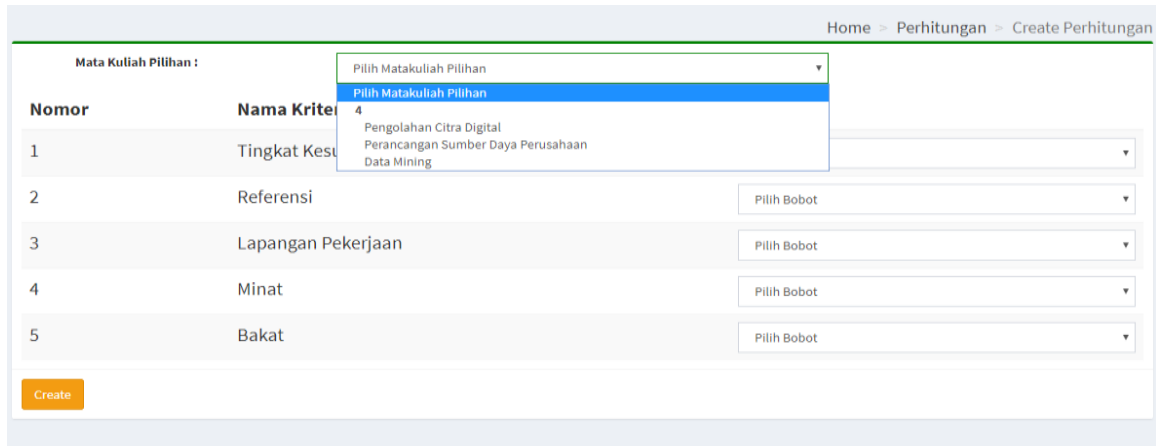

Gambar 11. Halaman Mahasiswa Semester IV

Mahasiswa memilih matakuliah yang ditampilkan, memilih bobot sesuai dengan Nama Kriteria yang disediakan. Ulangi untuk matakuliah pilihan yang lain. Selanjutnya untuk proses perhitungan klik tombol Create.

j) Tampilan Halaman Detail Perhitungan, merupakan tampilan halaman hasil perhitungan dari data yang telah di input. Adapun tampilannya terdiri dari:

- Hasil Perhitungan, lihat pada Gambar 12.

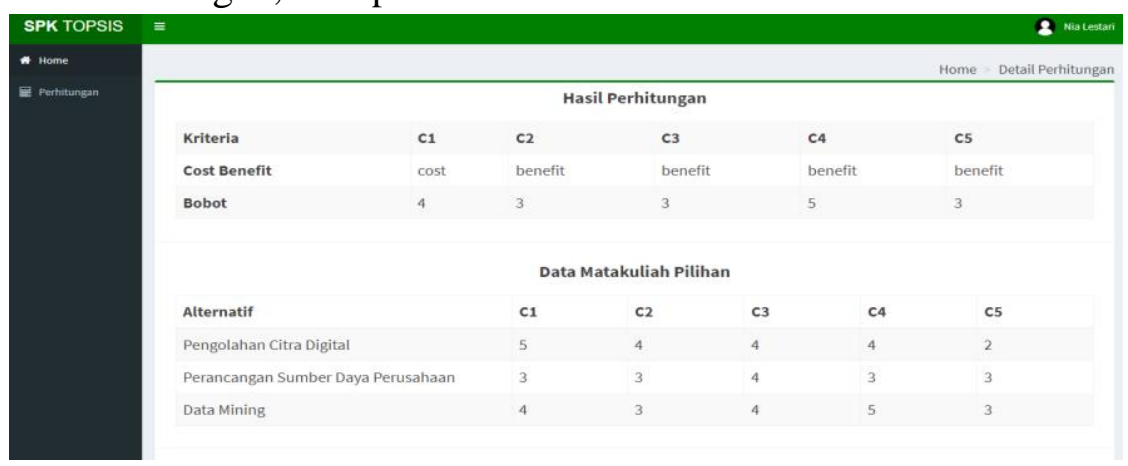

Gambar 12. Halaman Hasil Perhitungan 
- Matriks Ternormalisasi, lihat Gambar 13.

$\begin{array}{llllll} & \text { C1 } & \text { C2 } & \text { C3 } & \text { C4 } & \text { C5 } \\ \text { Pembagi } & 7,0710678 & 5,8309519 & 6,9282032 & 7,0710678 & 4,6904158\end{array}$

Data Matriks Keputusan yang Ternormalisasi

$\begin{array}{llllll}\text { Alternatif } & \text { C1 } & \text { C2 } & \text { C3 } & \text { C4 } & \text { C5 } \\ \text { Pengolahan Citra Digital } & 0,7071068 & 0,6859943 & 0,5773503 & 0,5656854 & 0,4264014 \\ \text { Perancangan Sumber Daya Perusahaan } & 0,4242641 & 0,5144958 & 0,5773503 & 0,4242641 & 0,6396021 \\ \text { Data Mining } & 0,5656854 & 0,5144958 & 0,5773503 & 0,7071068 & 0,6396021\end{array}$

Gambar 13. Halaman Matriks Ternormalisasi

- Matriks Terbobot, lihat Gambar 14.

Data Matriks Keputusan yang Terbobot

\begin{tabular}{|c|c|c|c|c|c|}
\hline Alternatif & C1 & $\mathbf{C 2}$ & C3 & C4 & C5 \\
\hline Pengolahan Citra Digital & 2,8284271 & 2,0579830 & 1,7320508 & 2,8284271 & 1,2792043 \\
\hline Perancangan Sumber Daya Perusahaan & 1,6970563 & 1,5434873 & 1,7320508 & 2,1213203 & 1,9188064 \\
\hline Data Mining & 2,2627417 & 1,5434873 & 1,7320508 & 3,5355339 & 1,9188064 \\
\hline \multicolumn{6}{|c|}{ Data Nilai Solusi Positif(A+) dan Negatif(A-) } \\
\hline & C1 & $\mathbf{C 2}$ & C3 & C4 & C5 \\
\hline $\mathbf{A}^{+}$ & 1,6970563 & 2,0579830 & 1,7320508 & 3,5355339 & 1,9188064 \\
\hline A- & 2,8284271 & 1,5434873 & 1,7320508 & 2,1213203 & 1,2792043 \\
\hline
\end{tabular}

\section{Gambar 14. Halaman Matriks Terbobot}

- Nilai Preferensi, lihat Gambar 15.

Data Jarak Solusi Ideal Positif(D+) dan Negatif(D-)

$\begin{array}{lcc}\text { Alternatif } & \text { D+ } & \text { D- } \\ \text { Pengolahan Citra Digital } & 2.80648 & 1.55601 \\ \text { Perancangan Sumber Daya Perusahaan } & 2.56147 & 2.50127 \\ \text { Data Mining } & 1.55601 & 2.80648\end{array}$

Data Nilai Preferensi(v)

$\begin{array}{ll}\mathbf{V} & \text { Nama Alternatif } \\ \mathbf{0 . 3 5 6 6 7} & \text { Pengolahan Citra Digital } \\ \mathbf{0 . 4 9 4 0 5} & \text { Perancangan Sumber Daya Perusahaan } \\ \mathbf{0 . 6 4 3 3 2} & \text { Data Mining }\end{array}$

Gambar 15. Halaman Nilai Preferensi

eISSN: 2477-3255, pISSN: 2086-4884 https://doi.org/10.31849/digitalzone.v11i1.3511 
- Halaman Perangkingan, lihat Gambar 16.

\begin{tabular}{lll} 
& & \multicolumn{1}{c}{ Perankingan } \\
Ranking & Nilai & Nama Alternatif \\
1 & $\mathbf{0 . 6 4 3 3 2}$ & Data Mining \\
2 & $\mathbf{0 . 4 9 4 0 5}$ & Perancangan Sumber Daya Perusahaan \\
3 & $\mathbf{0 . 3 5 6 6 7}$ & Pengolahan Citra Digital \\
& & \\
& & BPrint \\
\hline
\end{tabular}

Gambar 16. Halaman Perangkingan

Dari Gambar 16 terlihat bahwa untuk kasus mahasiswa semester IV, matakuliah Data Mining merupakan matakuliah pilihan prioritas yang perlu dipertimbangkan untuk diambil.

\section{Kesimpulan}

Perhitungan metode TOPSIS berdasarkan kriteria yang telah ditentukan yaitu tingkat kesulitan, referensi, lapangan pekerjaan, minat, dan bakat, serta bobot yang telah ditentukan pada masing-masing kriteria. Hasil akhir dari perhitungan adalah perangkingan matakuliah pilihan (alternatif) yang diurutkan dari nilai preferensi $\left(v_{i}\right)$ yang tertinggi. Untuk Kasus mahasiswa semester IV matakuliah pilihan berdasarkan rangking adalah Data Mining, Perancangan Sumber Daya Perusahaan, dan Pengolahan Citra Digital. Sedangkan untuk mahasiswa semester VI matakuliah pilihan berdasarkan rangking adalah Tatakelola dan Audit Sistem Informasi, Pengolahan Citra Digital, dan Data Mining.

\section{Daftar Pustaka}

[1] A. A. Chamid, "Penerapan Metode Topsis untuk Menentukan Prioritas Kondisi Rumah," $J$. SIMETRIS, vol. 7, no. 2, pp. 537-544, 2016.

[2] A. Jumadi, Z. Arifin, and D. M. Khairina, "Sistem Pendukung Keputusan Pemberian Kredit Rumah Sejahtera Pada Nasabah Bank Pembangunan Daerah Kalimantan Timur dengan Metode TOPSIS," J. Sist. Inf. Bisnis, vol. 4, no. 3, pp. 156-163, 2016.

[3] A. P. Windarto, "Implementasi Metode Topsis Dan Saw Dalam Memberikan Reward Pelanggan," Klik - Kumpul. J. Ilmu Komput., vol. 4, no. 1, p. 88, 2017.

[4] D. Herawatie and E. Wuryanto, "Sistem Pendukung Keputusan Pemilihan Mahasiswa Berprestasi dengan Metode Fuzzy TOPSIS," J. Inf. Syst. Eng. Bus. Intell., vol. 3, no. 2, p. 92, 2017.

[5] E. Kurniawan, H. Mustafidah, and A. Shofiyani, "Metode TOPSIS untuk Menentukan Penerimaan Mahasiswa Baru Pendidikan Dokter di Universitas Muhammadiyah Purwokerto ( TOPSIS Method to Determine New Students Admission at Medical School in University of," Juita, vol. 3, no. 4, pp. 201-206, 2015.

[6] N. Palasara and T. Baidawi, "Penerapan Metode Topsis Pada Peningkatan Kinerja Karyawan,” J. Inform. UBSI, vol. 5, no. 2, pp. 287-294, 2018.

[7] M. Salim, "Sistem Pendukung Keputusan Penerimaan Calon Guru Honor di SMK Gotong Royong Gorontalo Menggunakan Metode Topsis," J. Inform. Upgris, vol. 4, no. 1, 2018.

[8] F. S. Hutagalung, H. Mawengkang, and S. Efendi, "Kombinasi Simple Multy Attribute Rating (SMART) dan Technique For Order Preference by Similarity To Ideal Solution 
(TOPSIS) dalam Menentukan Kualitas Varietas Padi," InfoTekJar (Jurnal Nas. Inform. dan Teknol. Jaringan), vol. 3, no. 2, pp. 109-115, 2019.

[9] C. Surya, "Penilaian Kinerja Dosen Menggunakan Metode TOPSIS (Studi Kasus : Amik Mitra Gama)," J. RESTI (Rekayasa Sist. dan Teknol. Informasi), vol. 2, no. 1, pp. 322-329, 2018.

[10] A. M. Z. Wahyu, N. Safriadi, and H. S. Pratiwi, "Sistem Pendukung Keputusan Pemilihan Mata Kuliah Pilihan Menggunakan Metode Analytic Hierarchy Process ( studi kasus: Jurusan Teknik Elektro Fakultas Teknik Universitas Tanjungpur a )," J. Sist. dan Teknol. Inf., vol. 5, no. 2, pp. 160-163, 2017.

[11] F. A. Setyaningsih, "Analisis Kinerja Technique For Order Preference By Similarity To Ideal Solution (TOPSIS) Untuk Pemilihan Program Studi," J. Inform. J. Pengemb. IT Poltek Tegal, vol. 2, no. 2, pp. 43-46, 2017.

\section{(c) $\underset{\mathrm{BY}}{\mathrm{B} \text { (i) }}$}

